\title{
ON THE PRESENCE OF MEGATHERIUM CUVIER, 1796 (XENARTHRA, PILOSA) IN FOSSILIFEROUS DEPOSITS OF THE COASTAL PLAIN OF SOUTHERN BRAZIL
}

\author{
RENATO PEREIRA LOPES \\ Avenida Rio Grande, 45, caixa postal 15, 96207-000, Rio Grande, RS, Brazil. \\ paleonto_furg@yahoo.com.br \\ JAMIL CORREAA PEREIRA \\ Museu Coronel Tancredo Fernandes de Melo, Rua Barão do Rio Branco, 467, 96230-000, Santa Vitória do Palmar, RS, \\ Brazil. \\ jcorreapereira@bol.com.br
}

\begin{abstract}
The presence of the extinct sloth Megatherium americanum Cuvier in Pleistocene deposits of the Coastal Plain of the State of Rio Grande do Sul, southern Brazil, has been mentioned by several authors for decades, but formal descriptions of skeletal elements with unambiguous diagnostic features have never been published. The recent description of one dentary of the megatheriid Eremotherium laurillardi Lund from deposits in this area raised doubts about the taxonomic affinity of the materials assigned to M. americanum. The present work confirms the presence of the latter in the coastal plain of the state of Rio Grande do Sul (Santa Vitória do Palmar County), from a partial skull collected in fluvial deposits of the Santa Vitória Formation exposed on the banks of the Chuí Creek, plus an incomplete dentary, one tibia, one astragalus found on the shoreline, and another tibia with the fibula fused proximally and distally retrieved from the bottom of the continental shelf by the research vessel "Atlântico Sul". The fossils of both species of megatheriid sloths were found in the same deposits of Rio Grande do Sul (Chuí Creek in the coastal plain and Pessegueiro Creek in the central area of the state), which is remarkable given that E. laurillardi is known mostly from the intertropical Americas, whereas M. americanum is restricted to the subtropical-temperate regions of South America. Such co-occurrence could indicate that both species were sympatric or be related to the mixing by fluvial processes of remains of animals that occupied the same areas at distinct times due to periodic latitudinal shifts of the climatic belts.
\end{abstract}

Keywords: Megatheriidae, Megatherium, Pleistocene, paleobiogeography, paleoenvironment.

RESUMO - A presença da preguiça-gigante extinta Megatherium americanum Cuvier em depósitos do Pleistoceno na região costeira do sul do Brasil tem sido citada por diversos autores por décadas, mas descrições formais de elementos esqueletais com caracteres diagnósticos não foram ainda apresentadas. A recente descrição de um dentário do megaterídeo Eremotherium laurillardi Lund em depósitos desta região levantou dúvidas sobre a afinidade taxonômica dos materiais atribuídos a Megatherium. Aqui é confirmada a presença deste na Planície Costeira do Estado do Rio Grande do Sul (Município de Santa Vitória do Palmar), a partir de um crânio parcial coletado em um depósito fluvial da Formação Santa Vitória exposto nas barrancas do Arroio Chuí, um dentário incompleto, uma tíbia e um astrágalo encontrados na linha de costa, e de uma tíbia com a fíbula fusionada proximal e distalmente coletadas na plataforma continental pelo navio de pesquisas "Atlântico Sul". Nos mesmos depósitos do Rio Grande do Sul (Arroio Chuí na planície costeira e Arroio Pessegueiro no centro do estado) foram encontrados fósseis de ambas as espécies de megaterídeos, o que é notável, considerando que E. laurillardi é característico da zona intertropical das Américas, enquanto M. americanum é um táxon restrito à região subtropical-temperada da América do Sul. Essa co-ocorrência poderia indicar que ambas as espécies eram simpátricas (i.e. coexistiram ocupando distintos nichos ecológicos), ou estar relacionada à mistura por processos fluviais de restos de animais que ocuparam as mesmas áreas em épocas distintas devido a mudanças latitudinais periódicas das zonas climáticas.

Palavras-chave: Megatheriidae, Megatherium, Pleistoceno, paleobiogeografia, paleoambiente. 


\section{INTRODUCTION}

The Coastal Plain of the State of Rio Grande do Sul (CPRS), in southern Brazil, is known for the presence of rich fossil assemblages of middle to late Pleistocene. The most conspicuous taxa from these assemblages are megamammals (body mass $\geq 1,000 \mathrm{~kg}$ ), including several species of ground sloths (Paula Couto \& Cunha, 1965; Oliveira, 1992; 1996; Lopes \& Pereira, 2010; Pitana et al., 2013; Lopes, 2013).

In his mapping of the CPRS Delaney (1965) considered that the fossils found stranded along the shore were eroded from sediments of the Graxaim Formation (equivalent to the Alluvial Fans System of Villwock \& Tomazelli, 1995, see Figure 1), of "Tertiary" age. Delaney proposed that the presence of fossils of terrestrial mammals on the shore was because the Graxaim Formation extended in subsurface from the hinterland up to the continental shelf.

As the result of paleontological surveys along the CPRS during the 1950s and 1960s, Cunha (1959) and Paula Couto \& Cunha (1965) reported several mammalian remains collected along the shoreline and also from outcrops along the banks of Chuí Creek. These authors challenged the model of Delaney (1965), recognizing that the fossils found on the CPRS were of Pleistocene ("Bonaeran") age. Because no mammalian fossils had been found in the Graxaim Formation, Paula Couto \& Cunha (1965) considered that the fossils found along the Chuí Creek and shoreline were preserved in one large Pleistocene unit, which extended in subsurface from the creek up to the continental shelf. The assumption that the fossils belonged to the same stratigraphic level was followed by Soliani (1973), who described the stratigraphy of the outcrops along the Chuí Creek, assigning a "Lujanian" (sensu Pascual et al., 1966) age to the fossils and naming the fossil-bearing sediments as the Santa Vitória Formation (SVF) (for a review of the chronostratigraphy of the fossil-bearing deposits see Lopes, 2013).

One of the taxa mentioned by Paula Couto \& Cunha (1965) as occurring in the CPRS was Megatherium americanum Cuvier, 1796, and for decades the State of Rio Grande do Sul was regarded as the only Brazilian territory yielding fossils of that taxon (Paula Couto, 1975; 1979; Soliani, 1973; Oliveira, 1992; Lopes et al., 2008). Because they assumed the Pleistocene fossils came from one single lithostratigraphic unit (the SVF), Paula Couto \& Cunha (1965) did not specify whether the specimens identified as M. americanum were collected on the shoreline, in the Chuí Creek, or in both. Moreover, no specimens of $M$. americanum from those deposits were ever formally described or illustrated, as is the case of some other Pleistocene remains found in the CPRS (Lopes, 2013).

Considering the fragmentary nature of most of the remains found in the fossiliferous deposits of the CPRS, which often makes it difficult to reach a precise taxonomic assignment, and the recent description of a left dentary of Eremotherium laurillardi Lund, 1842 from Chuí Creek (Pereira et al., 2012), the presence of Megatherium americanum was considered dubious (Oliveira, 1996; Lopes, 2013). As part of an ongoing project focused on the fossils and geology of the CPRS, the review of the paleontological collections had led to the identification of previously unrecorded taxa and the reassessment of materials with dubious taxonomic assignment. Here is presented a result of that review, consisting of the description of fossils from the CPRS that bear diagnostic features of M. americanum, thus confirming the presence of this taxon in the Coastal Plain of southern Brazil.

\section{GEOLOGICAL SETTING}

The CPRS (Figure 1) is the uppermost portion of the Pelotas Basin, and encompasses two large sets of depositional systems: the Miocene-Pliocene Alluvial Fans (Closs, 1970), and four middle-late Pleistocene Barrier-Lagoon systems (Villwock \& Tomazelli, 1995). Each barrier-lagoon system was formed in response to an interglacial sea-level highstand and consists of long sandy barriers with lagoons, wetlands and fluvial systems developed on the backbarrier (Villwock \& Tomazelli, 1995; Buchmann et al., 2009). In the southern CPRS, two Pleistocene barrier-lagoon systems (II and III) and the Holocene system (IV) are preserved. The onshore fossiliferous deposits known so far in the southern CPRS are found in two major geomorphological units, namely the Lagoon System II, represented by Mirim Lake, and the Lagoon System III, along which the Chuí Creek flows. Other fossil concentrations are found in marine settings, from the shoreline to the inner continental shelf, up to depths of at least 40 meters (Villwock, 1984; Lopes \& Buchmann, 2010).

Chuí Creek, located seaward of Barrier II, has been known for the presence of fossils along its banks since the 1960s. Until the discovery of the aforementioned fossils in Mirim Lake this was the only known fossiliferous locality in the CPRS where mammalian remains can be assigned to a precise stratigraphic setting (Lopes et al., 2009). The banks of the creek rise up to 4-5 $\mathrm{m}$ above the creek bottom. The stratigraphic sequence shows at the base sediments deposited in a shallow marine environment (upper shoreface-foreshore) and contain the ichnofossils Ophiomorpha nodosa and Rosselia sp. (Figure 2). Fossil shells and sediments from within this layer were dated as older than $220 \mathrm{ka}$, and assigned to Barrier System II (Rosa, 2012; Lopes et al., 2014a,b). The marine layer is overlain by paleosols, eolian and fluvial deposits of the SVF in which the mammalian remains are preserved. Electron spin resonance (ESR) and thermoluminescence (TL) dating of fossil teeth and sediments collected in the SVF indicate that the fossil assemblage was formed between 226 and $34 \mathrm{ka}$ ago at least (Lopes et al., 2010, 2014b), thus biostratigraphically corresponding to Bonaeran-Lujanian Stage/Ages (sensu Cione \& Tonni, 1999). Most of the assemblage consists of disarticulated and/or fragmented remains, but some articulated specimens have been found (Lopes \& Ferigolo, 2015). The SVF is overlain by the loess deposits of the Cordão Formation (Lopes et al., 2016) and modern soils at the top.

The fossiliferous concentrations on the inner continental shelf consist of transgressive lag deposits, formed by remains of different ages mixed together by erosive and depositional processes related to cyclical, glacially-driven marine transgressions that formed the coastal barriers. 


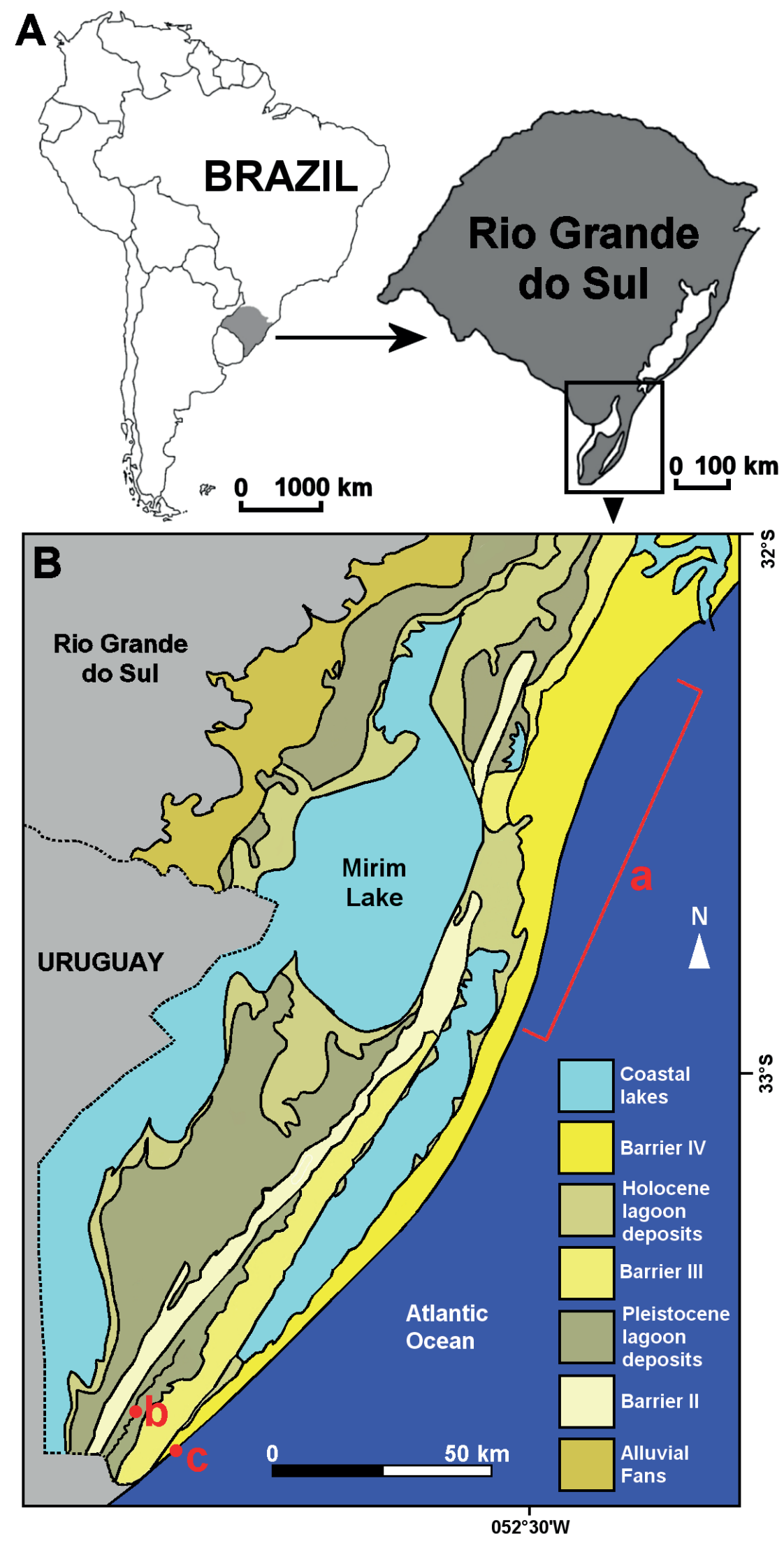

Figure 1. A, location of the southern CPRS; B, geological map of the southern CPRS (modified from Villwock \& Tomazelli, 1995; Rosa, 2012), showing the provenience of the fossils described in the text: a, continental shelf, $\mathbf{b}$, Chuí Creek, $\mathbf{c}$, Hermenegildo Beach. 

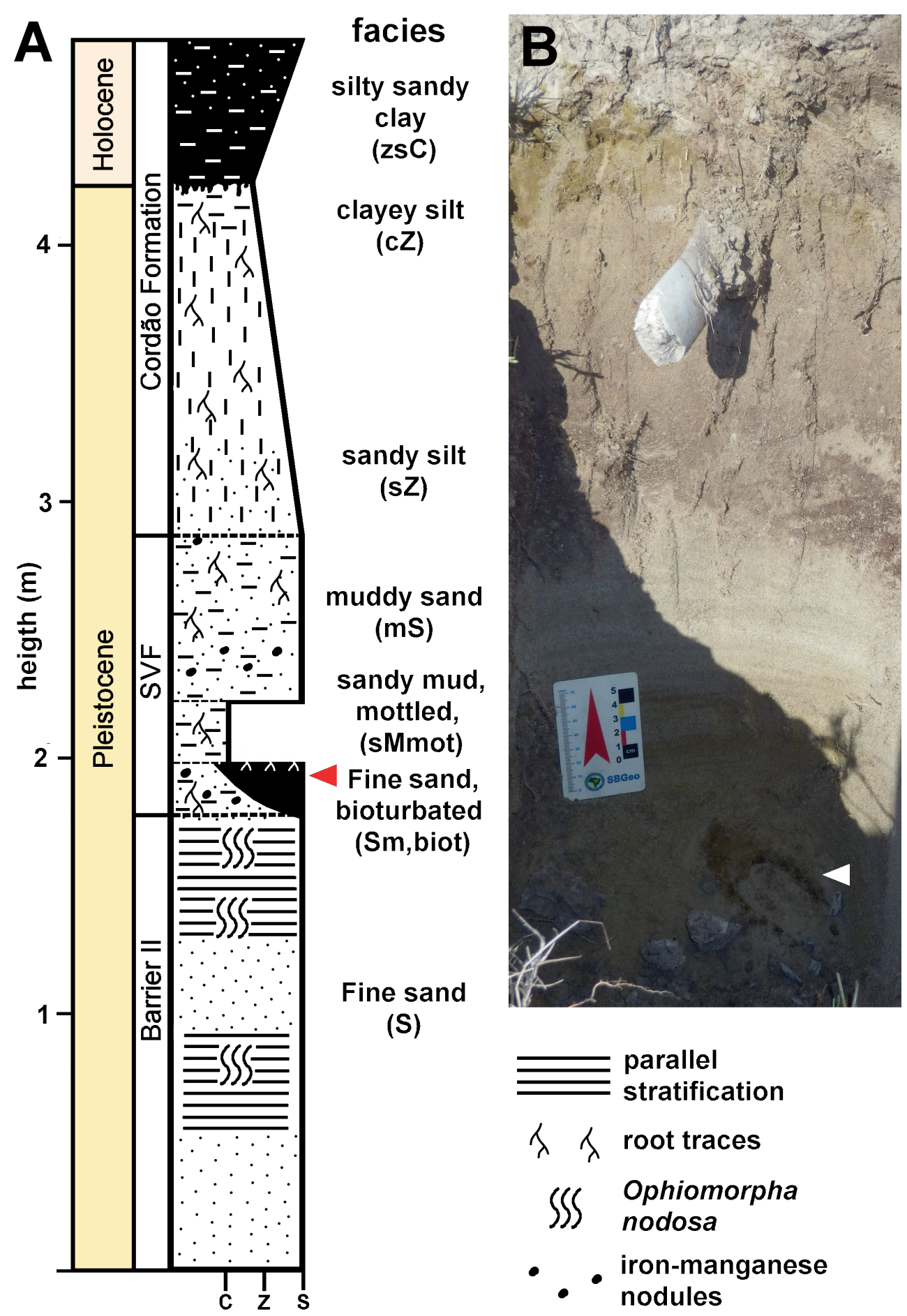

Figure 2. A, stratigraphic section of the outcrop on the left bank of Chuí Creek where the skull MCTFM-PV0722 was found (indicated by the arrow). B, detail of the erosive contact between the marine deposits of the Barrier II (with an ichnofossil Ophiomorpha nodosa indicated by the white arrow) and the overlying fossil-bearing SVF, with a fragmented rib partially exposed (c, clay; s, sand; $\mathbf{z}$, silt).

Today, those deposits are being eroded by storm waves that transport the fossils to the shore, thus forming large Konzentrat-Lagerstätten on the beach (Figueiredo, 1975; Lopes \& Buchmann, 2008; 2010). These concentrations include remains of both marine and terrestrial organisms, the latter represented by animals that inhabited the continental shelf during periods when it was subaerially exposed due to sea-level lowstands (Lopes \& Buchmann, 2010; Lopes et al., 2010; Aires \& Lopes, 2012).

One major problems regarding the fossil remains from the shelf is the lack of a stratigraphic setting, because of the erosion of the upper 3-10 $\mathrm{m}$ of these deposits by the advancing sea-level during the interglacial marine transgressions (Dillenburg, 1996), which reworked and mixed together fossils of different ages. As a result, the mammalian fossil 
assemblage from the shelf includes remains ranging in age from 18 to $>650 \mathrm{ka}$ (Lopes et al., 2010), thus representing from Ensenadan to Lujanian Stage/Age. Besides reworking by long-term processes (sea-level oscillations), the fossils found on the inner shelf are also subject to short-term processes (waves and currents), resulting in disarticulated, broken and abraded remains (Lopes et al., 2008; Lopes \& Ferigolo, 2015), many of them lacking unambiguous diagnostic features.

\section{MATERIAL AND METHODS}

The fossils identified here as Megatherium were found in the Santa Vitória do Palmar County and include one skull collected in a fluvial deposit of the SVF exposed on the left bank of Chuí Creek, besides one tibia and one astragalus found on Hermenegildo Beach (Figure 1B). These specimens are deposited at the Museu Coronel Tancredo Fernandes de Mello, in the town of Santa Vitória do Palmar. Another specimen is a tibia-fibula retrieved from the continental shelf (Figure 1B) and deposited at the Museu de Ciências Naturais (Seção de Paleontologia) of the Fundação Zoobotânica do Rio Grande do Sul, in the City of Porto Alegre, Rio Grande do Sul.

Identification of the specimens was performed through comparison with published descriptions of species of Megatherium and Eremotherium (Clift, 1835; Owen, 1861; Ameghino \& Kraglievich, 1923; Cartelle \& Bohórquez, 1982; Toledo, 1986; 1998; Cartelle, 1992; De Iuliis, 1996, 1995; Oliveira et al. 2002; Brandoni et al., 2004; 2008; Cartelle \& De Iuliis, 2006; McDonald, 2012; Toledo et al., 2017).

Abbreviations: MCN-PV, Museu de Ciências Naturais Paleontologia de Vertebrados, Fundação Zoobotânica do Rio Grande do Sul, Porto Alegre, Brazil; MCTFM-PV, Museu Coronel Tancredo Fernandes de Mello - Paleontologia de Vertebrados, Santa Vitória do Palmar, Brazil.

\section{SYSTEMATIC PALEONTOLOGY}

\author{
MAMMALIA Linnaeus, 1758 \\ XENARTHRA Cope, 1889 \\ PILOSA Flower, 1883 \\ MEGATHERIIDAE Owen, 1843 \\ MEGATHERIINAE Gray, 1821
}

Megatherium Cuvier, 1796

Megatherium americanum Cuvier, 1796

(Figures 3-7)

Material. MCTFM-PV0772 (Figure 3), incomplete skull. Stratigraphic provenance. MCTFM-PV0722 was found on the left bank of Chuí Creek, partially exposed by erosion. At this outcrop the bank reaches about $5 \mathrm{~m}$ above the creek (Figure 2A). The lowermost portion of the banks consists of the sandy facies (S) of Barrier II. The fossil-bearing sediment is a $\sim 30$ centimeter-thick and $\sim 4$ meter-long lensshaped fluvial deposit (channel architectural element, $\mathrm{CH}$, sensu Miall, 1985) of the SVF, lying in erosive contact with the marine sediments below and bounded laterally by muddy sandy paleosols containing plant root traces and ironmanganese masses. The sediment that filled the channel is a brown (color 5YR 3/2 in the Munsell scale) massive sand that grades vertically to a yellowish (10YR 4/2) bioturbated sandy mud stained by iron oxide, which is overlain by a grayish (10YR 6/2) sandy clay and muddy sand with plant roots and iron-manganese masses. Although sedimentary structures are not preserved, this sequence seems to indicate a fluvial channel that became filled with sediment, with palaeosols developing on top of it. The interpretation of a relatively medium to high energy fluvial system is indicated by the presence of a fragmented rib close in the same deposit where the skull was recovered (Figure 3B).

Description and comments. Incomplete skull (Figure 4), measuring $738 \mathrm{~mm}$ in length. The skull was found lying on its right side; most of the left side and parietal-occipital portions were destroyed either due to incomplete burial or by erosion after burial. The absence of visible sutures indicates an adult individual. The M1 and M2 are absent in the right dental series, whereas the only remaining tooth of the left series is the M4. Diagnosed as Megatherium americanum by the following characters: elongated and narrow quadrangular premaxillae, expanded and fused to each other and to the maxillae (in Eremotherium laurillardi the premaxillae are small, triangular-shaped and unfused, whereas in M. gallardoi C. Ameghino \& Kraglievich, 1921 the premaxillae are weakly fused, as indicated by distinct sutures). The nasal region is tall and wide, the rostrum being wider than in E. laurillardi (Table 1), but less inflated laterally than in M. gallardoi. The anterior end of the body of the jugal is fused to the zygomatic process of the maxilla above the M1 (as in E. laurillardi). The orbital process of the jugal is triangular, directed anteriorly and is more developed than in M. gallardoi, and the ascending process is less postero-dorsally projected than in M. gallardoi. The ventral margin of the orbit is positioned above the cranial alveolar margin (it lies at the same level of the molariform series in E. laurillardi). The minimum palatal width between the dental series is slightly wider than the largest molariform tooth (twice this width in E. laurillardi according to Cartelle \& Bohorquez, 1982, but see Toledo, 1986), and positioned at the level of the M2 (in E. laurillardi it is positioned at the level of the M2 or M3). The dental series is almost straight (lingually convex in E. laurillardi). The length of the dental series and the size of the teeth are larger than measured in E. laurillardi, falling within the range observed in M. americanum (Table 1).

Material. MCTFM-PV0778, left dentary (Figure 4).

Stratigraphic provenance. This specimen was found stranded on Hermenegildo Beach, transported by waves from the fossil concentrations on the inner continental shelf therefore its precise stratigraphic position is unknown. The electron spin resonance (ESR) ages from teeth collected along the beach indicate that the fossils from the shelf are correlated to the Ensenandan - Lujanian stages (Lopes et al., 2010). 


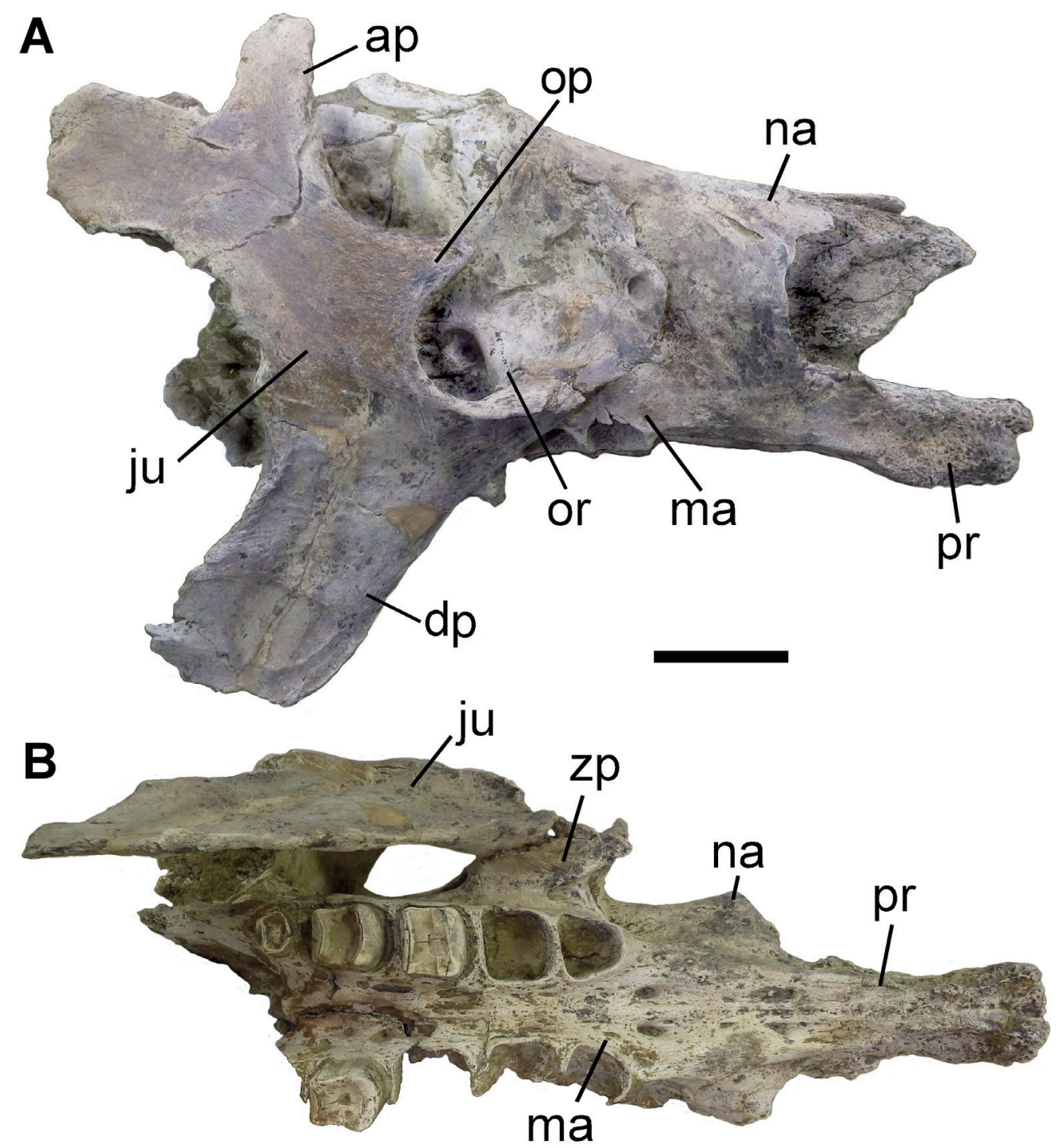

Figure 3. Skull of Megatherium americanum (MCTFM-PV0772) in lateral (A) and ventral (B) views. Abbreviations: ap, ascending process of the zygomatic arch; dp, descending process of the zygomatic arch; ju, jugal; ma, maxilla; na, nasal; op, orbital process of the jugal; or, orbita; pr, premaxilla; zp, zygomatic process of the maxilla. Scale bar $=100 \mathrm{~mm}$.

Table 1. Measurements (in mm) of the skull MCTFM-PV0772, compared with the range of variation observed in Megatherium americanum and Eremotherium laurillardi, from (a) De Iuliis (1996), (b) Clift (1835) and (c) Cartelle (1992). Abbreviations: ANTW, rostrum width anterior to the anterior zygomatic root; BL, buccolingual length; ML, mesiodistal length; TRL, tooth row length. *Only alveolar dimensions.

\begin{tabular}{|c|c|c|c|c|}
\hline \multicolumn{2}{|c|}{ Measure } & MCTFM-PV0772 & M. americanum & E. laurillardi \\
\hline \multicolumn{2}{|c|}{ ANTW } & 155 & 115-177 (a) & $120-133$ (a) \\
\hline \multicolumn{2}{|c|}{ TRL } & 273.25 & 200-270 (a) & 192-214 (a) \\
\hline \multirow{2}{*}{ M1 } & ML & $* 43.66$ & $35.5(b)$ & $20-42$ (c) \\
\hline & $\mathrm{BL}$ & $* 47.71$ & 45.7 (b) & $22-41(c)$ \\
\hline \multirow{2}{*}{ M2 } & ML & $* 51.41$ & $50.8(b)$ & 26-44 (c) \\
\hline & $\mathrm{BL}$ & $* 51.49$ & 45.7 (b) & 26-49 (c) \\
\hline \multirow{2}{*}{ M3 } & ML & 49.34 & $53.3(b)$ & $25-45(\mathrm{c})$ \\
\hline & $\mathrm{BL}$ & 51.41 & $43.1(b)$ & $27-50(\mathrm{c})$ \\
\hline \multirow{2}{*}{ M4 } & ML & 54.23 & $\mathrm{X}$ & $23-42$ (c) \\
\hline & $\mathrm{BL}$ & 49.32 & $\mathrm{X}$ & $23-47$ (c) \\
\hline \multirow{2}{*}{ M5 } & ML & 23.25 & $\mathrm{X}$ & $12-19$ (c) \\
\hline & $\mathrm{BL}$ & 29.58 & $\mathrm{X}$ & $19-26(\mathrm{c})$ \\
\hline
\end{tabular}



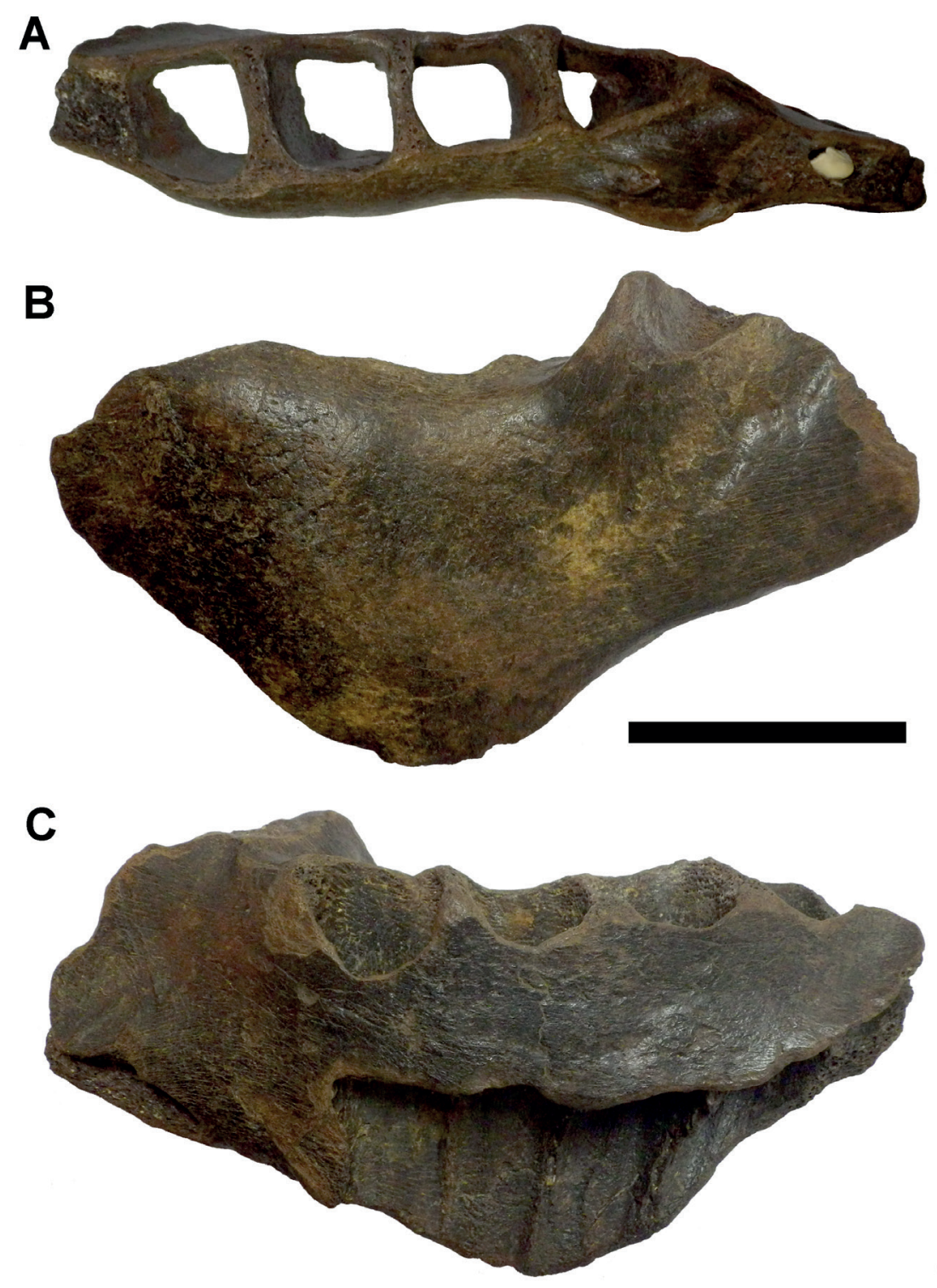

Figure 4. Incomplete dentary of Megatherium sp. (MCTFM-PV0778) in dorsal (A), lateral (B) and medial (C) views. Scale bar $=50 \mathrm{~mm}$.

Description and comments. MCTFM-PV0778 is an incomplete left dentary, exhibiting signs of abrasion and dark color that are common in fossils found on the beach (Lopes et al., 2008; Lopes \& Ferigolo, 2015). The outlines of the alveoli clearly indicate that it is a megatheriinae, but most of the diagnostic features are lacking due to the loss of the symphyseal and articular areas. Nevertheless, it is assigned to Megatherium based on the proportion between the maximum body height (MBH) and the maximum tooth row length (MTRL), which yielded a value of 87.4 (Table 2). Even though the ventral margin of the body is abraded, this proportion is larger than the highest range observed in Eremotherium (De Iuliis, 1996). The proportion, however, is smaller than recorded for M. americanum, therefore it could represent an ontogenetic variation of this species, being less developed in juvenile individuals (De Iuliis, 1996), or indicate that this is another species of Megatherium. In fact, Ameghino \& Kraglievich (1921) observed that the ventral bulge of the dentary is less developed in M. gallardoi, with a MBH/ MTRL proportion of 87.8 (Table 2), similar to that measured in MCTFM-PV0778. This suggests that the latter could be M. gallardoi, but the smaller dimensions of this specimen indicate a sub-adult individual, therefore the possibility that it belongs to a young $M$. americanum cannot be excluded. In the absence of more diagnostic features, MCTFM-PV0778 is assigned to Megatherium sp.

Material. MCTFM-PV1098, left tibia (Figure 5).

Stratigraphic provenance. Hermenegildo Beach, as the dentary described above.

Description and comments. Complete specimen, measuring $481 \mathrm{~mm}$ in length (Table 3), with signs of abrasion on its proximal and distal ends. The longitudinal cracks along the diaphysis and reticular cracks on the articular surfaces suggest some period of exposure to weathering prior to fossilization (Behrensmeyer, 1978; Lopes \& Ferigolo, 2015). Although most of the fibula is missing, its remaining 
Table 2. Measurements (in mm) of the dentary MCTFM-PV0778, compared with the range of variation observed in Megatherium americanum, M. gallardoi and Eremotherium laurillardi, from (a) De Iuliis (1996), (b) Ameghino \& Kraglievich (1921), and (c) Cartelle (1992). Abbreviations: BL, buccolingual length; MBH, maximum body height; ML, mesiodistal length; MTRL, maximum tooth row length. *Alveolar dimensions.

\begin{tabular}{|c|c|c|c|c|c|}
\hline \multicolumn{2}{|c|}{ Measure } & MCTFM-PV0778 & M. americanum & M. gallardoi & E. laurillardi \\
\hline \multicolumn{2}{|c|}{ MBH } & 153.1 & $180-254$ (a) & 196 (b) & $127-156$ (a) \\
\hline \multicolumn{2}{|c|}{ MTRL } & 175 & 186-259 (a) & $223(b)$ & $174-200$ (a) \\
\hline \multicolumn{2}{|c|}{ MBH/MTRL } & 87.4 & $97.2-112$ (a) & 87.8 & $66.3-83$ (a) \\
\hline \multirow{2}{*}{$\mathrm{m} 1$} & ML & $* 33.5$ & $41-46.8$ (b) & *47 (b) & $28-42(c)$ \\
\hline & $\mathrm{BL}$ & $* 42$ & $46.2-51.3(b)$ & $* 58.2(\mathrm{~b})$ & $28-44(c)$ \\
\hline \multirow{2}{*}{$\mathrm{m} 2$} & ML & $* 40$ & $40-48.7$ (b) & $41.6-* 44.7$ (b) & $29-46$ (c) \\
\hline & $\mathrm{BL}$ & $* 40.5$ & $49-57.3(b)$ & $58.4-60.4(\mathrm{~b})$ & $30-47$ (c) \\
\hline \multirow{2}{*}{$\mathrm{m} 3$} & ML & $* 42.5$ & $43-51.6$ (b) & 47.7 (b) & 29-44 (c) \\
\hline & $\mathrm{BL}$ & $* 33.5$ & $47-48.8$ (b) & $52(b)$ & $28-46$ (c) \\
\hline \multirow{2}{*}{$\mathrm{m} 4$} & ML & $* 39.5$ & $\mathrm{X}$ & $\mathrm{X}$ & $26-41$ (c) \\
\hline & $\mathrm{BL}$ & $* 33$ & $\mathrm{X}$ & $\mathrm{X}$ & $23-41(\mathrm{c})$ \\
\hline
\end{tabular}
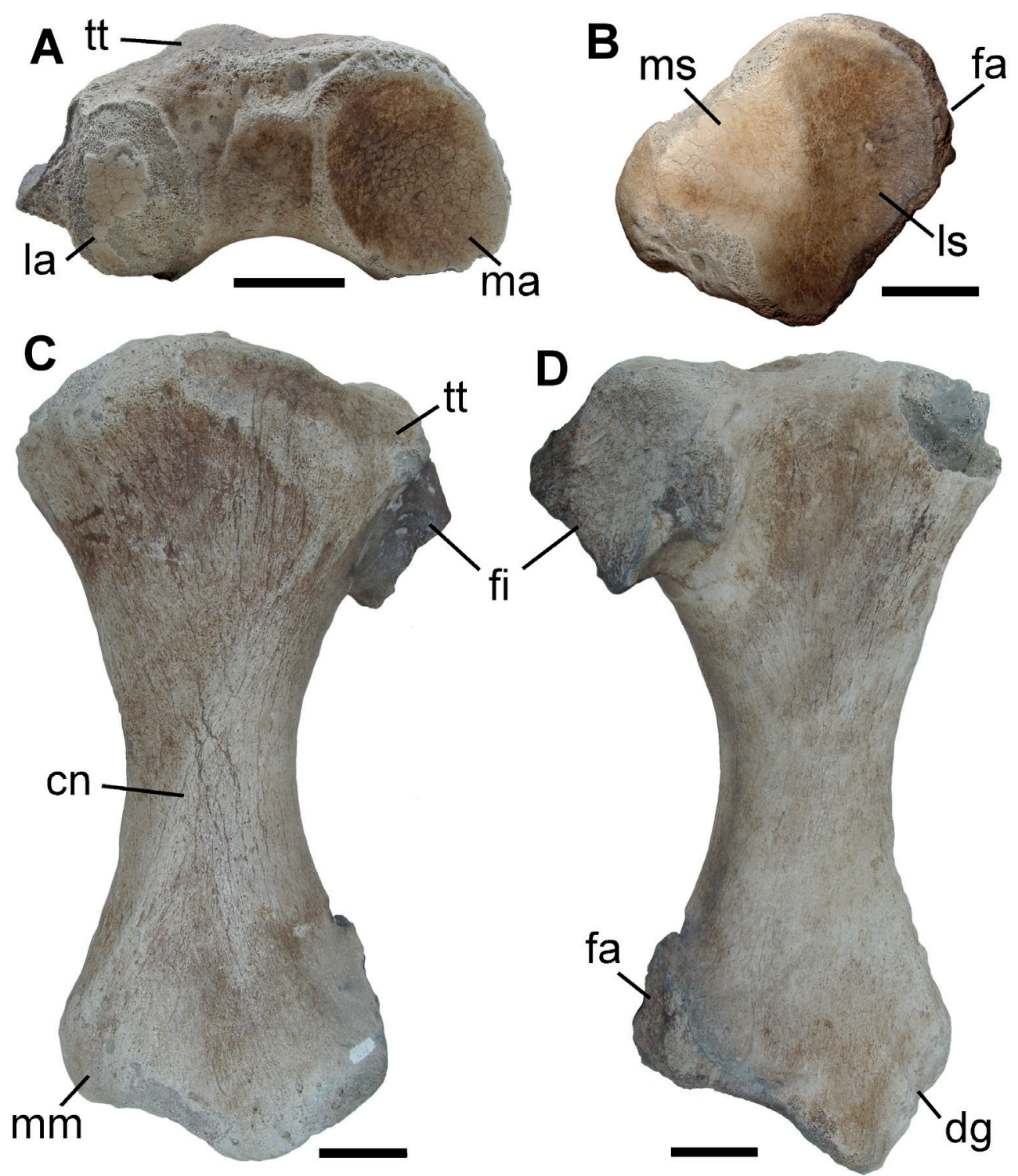

Figure 5. Left tibia of M. americanum (MCTFM-PV1098) in proximal (A), distal (B, the dashed line shows the approximate outline of the portion that was removed by abrasion), anterior (C) and posterior (D) views. Abbreviations: cn, cnemial crest; dg, digital groove; fa, fibular attachment; fi, fibula; la, lateral proximal articular surface; Is, lateral distal articular surface; ma, medial proximal articular surface; mm, medial malleolus; ms, medial distal articular surface; tt, tibial tuberosity. Scale bars $=50 \mathrm{~mm}$. 
Table 3. Measurements (in mm) of the tibiae (MCTFM-PV1098 and MCN-PV1115) and astragalus (MCTFM-PV1176), compared with the range of variation observed in Megatherium americanum and Eremotherium laurillardi, from De Iuliis (1996). Abbreviations: DWWOF, maximum distal width without fibula; MSWIDTH, minimum transverse width at midshaft; PWIDTH, greatest proximal width.

\begin{tabular}{|c|c|c|c|c|}
\hline Tibia & MCTFM-PV1098 & MCN-PV1115 & M. americanum & E. laurillardi \\
\hline Length & 481.3 & 553 & $425-623$ & $447-665$ \\
\hline Pwidth & 253.5 & 331.9 & $246-369$ & $245-405$ \\
\hline Mswidth & 95.7 & 110.2 & $81-141$ & $91-144$ \\
\hline Dwwof & 191.4 & 191.6 & $182-250$ & $172-271$ \\
\hline Astragalus & \multicolumn{2}{|c|}{ MCTFM-PV1176 } & M. americanum & E. laurillardi \\
\hline Length & \multicolumn{2}{|c|}{230} & $163-238$ & $169-259$ \\
\hline Heigth & \multicolumn{2}{|c|}{155} & $169-253$ & $175-256$ \\
\hline
\end{tabular}

proximal end is fused to the proximolateral part of the tibia, which is characteristic of Megatheriinae. The diaphysis is constricted in the middle, whereas the proximal and distal ends are mediolaterally expanded. The proximal end of the tibia is compressed anteroposteriorly and anteriorly arched, a feature of E. laurillardi but also occurring in $M$. americanum (De Iuliis, 1996). The medial articular surface for the femoral medial condyle is concave and oval-shaped, with the long axis obliquely oriented anteroposteriorly. The lateral articular surface is smaller, oval, and mediolaterally and anteroposteriorly convex; its width is almost equal to the space between the two articular surfaces. The tibial tuberosity is triangular, positioned laterally to the sagittal plane of the tibia, with a shallow proximodistal groove, and the cnemial crest originating from it crosses the diaphysis to reach the medial malleolus, which bears a digital groove on its posterior portion. The fibular attachment surface is rugose, and shows that the fibula was not fused distally to the tibia. Fusion between the fibula and tibia distally may occur in old individuals of $M$. americanum (Cuvier, 1804; Cartelle, 1992), whereas in $E$. laurillardi such fusion was not observed (De Iuliis, 1996).

The features that allow identification of this tibia as belonging to Megatherium americanum are found in its distal end (Figure 5B): it is more expanded anteroposteriorly (see De Iuliis, 1996, pl. 107E), whereas in Eremotherium laurillardi it is compressed (De Iuliis, 1996, pl. 105E). The posterodistal margin is more convex than in E. laurillardi and the medial articular surface (for the odontoid facet of the astragalus) lies adjacent to the central portion of the lateral articular surface (for the discoid facet), whereas in E. laurillardi it is located more posteriorly (Cartelle, 1992; De Iuliis, 1996). The medial surface is short, but wider on its medial side, and its long axis is perpendicular to the lateral surface. The lateral articular surface is crescent-shaped, elongated anteroposteriorly, and separated from the medial articular surface by an arched medial ridge that is mediolaterally smooth. The angle formed between these two surfaces, measured across the medial ridge, is nearly $120^{\circ}$, which is consistent with the obtuse angle between the odontoid and discoid facets in the astragalus of M. americanum (see below).

Material. MCN-PV1115, right tibia and fibula (Figure 6). Stratigraphic provenance. This specimen was retrieved from the bottom of the continental shelf off the southern CPRS by the research vessel "Atlântico Sul" of Universidade Federal do Rio Grande (FURG) in the 1980s and donated to the Museu de Ciências Naturais by Dr. Eliézer de Carvalho Rios. The exact provenance is unknown, but it was described as retrieved at a depth of some $20 \mathrm{~m}$, between Cassino Beach and Albardão lighthouse (Figure 1B).

Description and comments. The specimen is almost complete, except for some highly abraded areas on the posterior surfaces of the proximal and distal ends. The abrasion removed part of the proximolateral end of the fibula, thus reducing its proximal width (Table 3 ). The abraded surfaces are characteristic of fossils subject to waves and currents in the upper shoreface-foreshore (Lopes et al., 2008; Lopes \& Ferigolo, 2015), but the presence of several episkeletozoans (oysters, corals, bryozoans, polychaetes) on the bone surface is typical of fossils that remain exposed at the water-sediment surface below the action of waves (Lopes $\&$ Buchmann, 2010). It is slightly larger (Table 3 ) than the tibia MCTFM-PV1098 described above, but the anatomical features are essentially the same, the major differences being the tibial tuberosity less prominent, the medial wall of the medial malleolus taller and less rounded, and the fibula fused to the tibia both proximally and distally, a feature known so far only in old individuals of Megatherium (Cuvier, 1804; Cartelle, 1992; De Iuliis, 1996). The length of the proximal tibiofibular attachment area is the same in both specimens (about $129 \mathrm{~mm}$ ), but the distal attachment area is larger (about $150 \mathrm{~mm}$ ) in this specimen ( $90 \mathrm{~mm}$ in MCTFM-PV1098). The fusion is so complete that no suture between both bones is visible, except in the tibial cochlea (Figure 6B). Although the posterodistal margin is more convex in M. americanum than in Eremotherium laurillardi, this character could not be properly assessed because this margin is highly abraded (Figure 6B). Other diagnostic features of Megatherium observed in this specimen are the obtuse angle (nearly $\sim 120^{\circ}$ ) formed by the lateral and medial distal articular surfaces for the astragalus, and the rounded, almost circular medial surface. Despite the abraded state, tibial trochlea seems more expanded anterioposteriorly than in E. laurillardi (De Iuliis, 1996, pl. 105E and pl. 107E).

Material. MCTFM-PV1176, left astragalus (Figure 7). Stratigraphic provenance. Found on Hermenegildo Beach, as the dentary and tibia described above. 
Description and comments. The specimen is incomplete due to abrasion of the surface, which exposed the internal spongy structure of the bone, a feature common among fossils found on the beach (Lopes \& Ferigolo, 2015). The signs of abrasion are more evident on the fibular (Figure 7E) and tibial (Figure 7F) sides. Although somewhat reduced in length and height as a result of abrasion, its dimensions fall within the larger end of the range of variation in giant megatheriines (Table 3). It is diagnosed as Megatherium americanum by the following features: the mediodorsal portion of the navicular facet positioned slightly below the plane of the discoid facet in medial view (Figure 7E; in Eremotherium laurillardi it is dorsally projected above the discoid facet). The odontoid tuberosity is less developed than in other megatheriines. The odontoid process is rounded, slightly wider at the contact with the discoid facet, whereas it is more elongated, almost cylindrical in E. laurillardi (see De Iuliis, 1996, pls. 110, 111 and 112). The contact between the odontoid and discoid facets is more rounded, consistent with the smooth ridge between the odontoid and discoid facets in the tibial cochlea, whereas in E. laurillardi it is more angular. The angle between the discoid and odontoid facets as seen from the anterior view is $\sim 118^{\circ}$ (Figure 7B), but in E. laurillardi this angle is about $90^{\circ}-110^{\circ}$ (De Iuliis, 1996). The sustentacular facet is small and separated from the ectal facet by relatively narrow and deep sulcus tali. The ectal facet is slightly concave medioposteriorly and convex mediolaterally; compared to E. laurillardi its anterior margin lies more posteriorly to the estimated position of the fibular facet, and it slopes upward posteriorly, thus approaching the
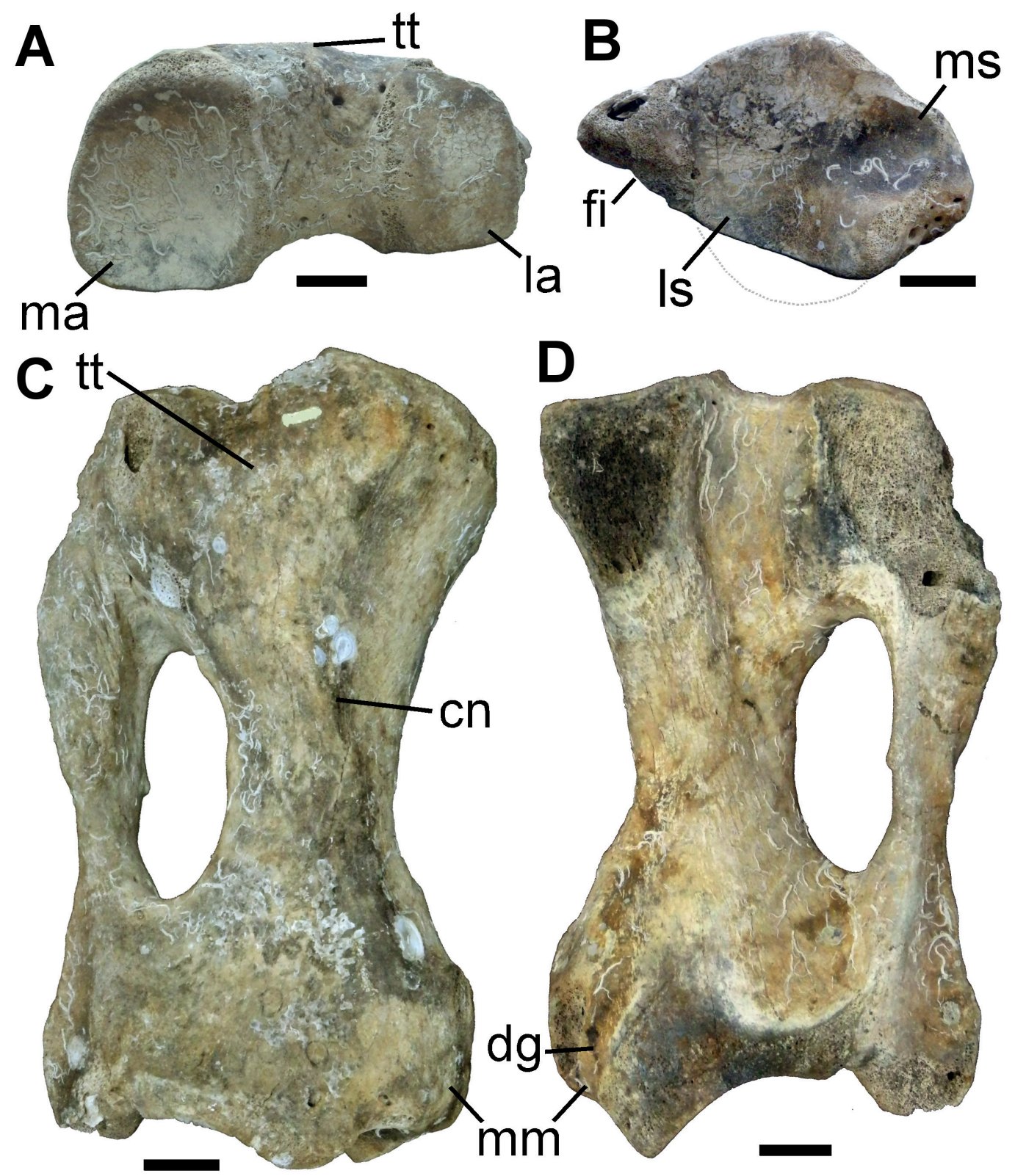

Figure 6. Right tibia and fibula (MCN-PV1115) in proximal (A), distal (B) with a dotted line showing the portion that was removed by abrasion, anterior (C) and posterior (D) views. Abbreviations: cn, cnemial crest; dg, digital groove; fi, fibula; la, lateral proximal articular surface; ls, lateral distal articular surface; ma, medial proximal articular surface; $\mathbf{m m}$, medial malleolus; $\mathbf{m s ,}$, medial proximal articular surface; tt, tibial tuberosity. Scale bars $=50 \mathrm{~mm}$. 

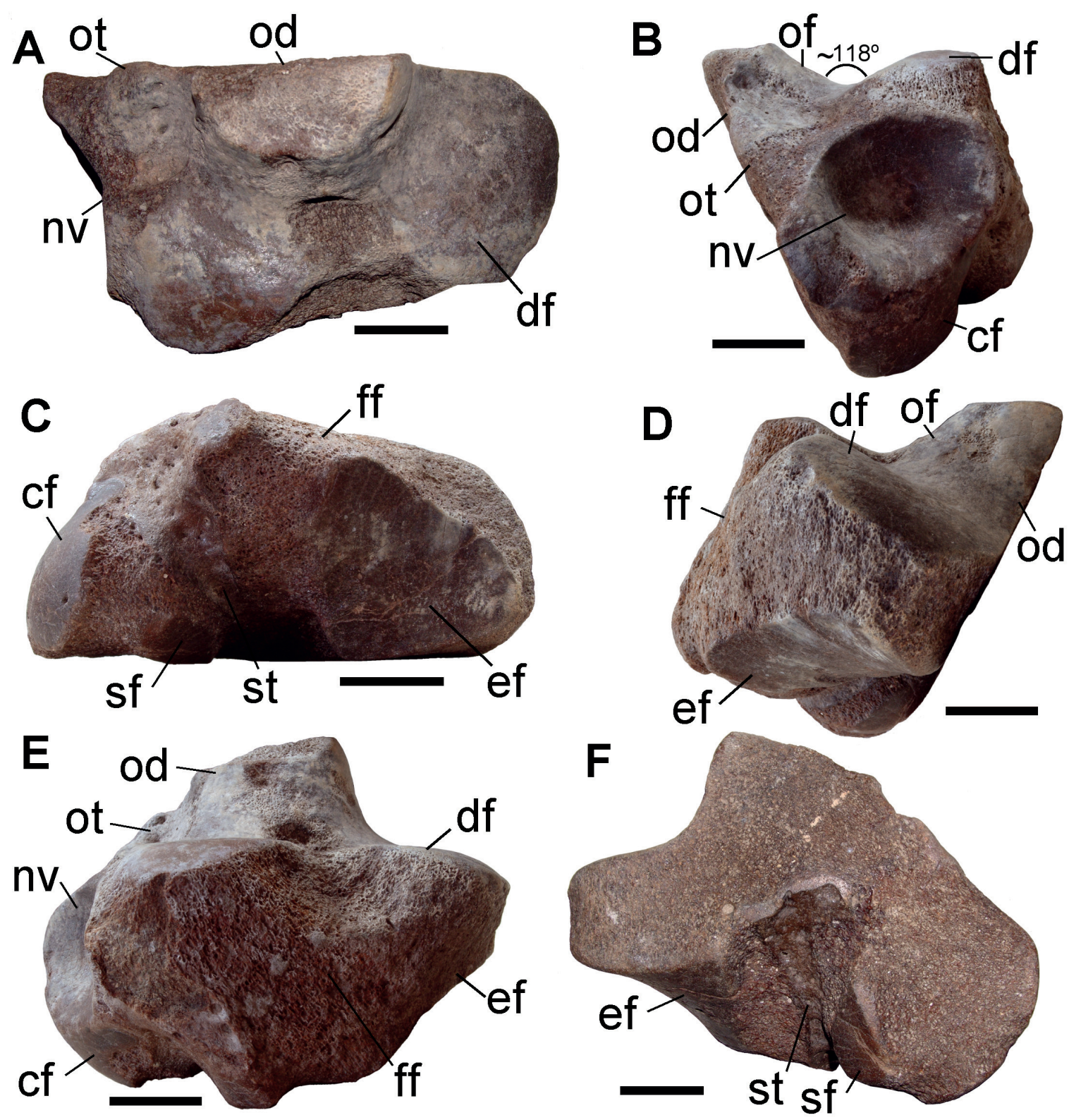

Figure 7. Left astragalus (MCTFM-PV1176) in proximal (A), anterior (B, also showing the angle between the odontoid and discoid facets), distal (C), posterior (D), lateral (E) and medial (F) views. Abbreviations: cf, cuneiform facet; df, discoid facet; ef, ectal facet; ff, fibular facet (absent due to abrasion); nv, navicular facet; od, odontoid process; of, odontoid facet; ot, odontoid tuberosity; sf, sustentacular facet; st, sulcus tali. Scale bars $=50 \mathrm{~mm}$.

discoid facet, although the abraded state of the specimen does not allow to assess how close the two facets reach (they approach each other more closely in $M$. americanum than in E. laurillardi; De Iuliis, 1996).

\section{DISCUSSION}

The remains described here represent the first unequivocal evidence for the presence of Megatherium americanum in the CPRS, increasing to six the number of extinct sloth species known from the fossil assemblages of that area (Oliveira, 1992; 1996; Lopes \& Pereira, 2010; Pereira et al., 2012; Pitana et al., 2013), which include, besides the megatheriids $M$. americanum and Eremotherium laurillardi, the mylodontids Lestodon armatus Gervais, 1855, Glossotherium robustum (Owen, 1842), Mylodon darwinii Owen, 1840 and Catonyx cf. C. cuvieri (Lund, 1839) (Figure 8).

Despite the incomplete state of some specimens, the morphological features allow identifying these remains as belonging to Megatherium americanum. The dubious specific assignment of the dentary MCTFM-PF0778 results of the loss of its posterior and anterior ends and the small size which suggests that it could be a sub-adult individual of either $M$. americanum or M. gallardoi, based on the similar MBH/ MTRL with the latter. Although the latter species is known so far from the Ensenadan deposits of Argentina (Brandoni et al., 2008), the hypothesis of its presence in the CPRS 


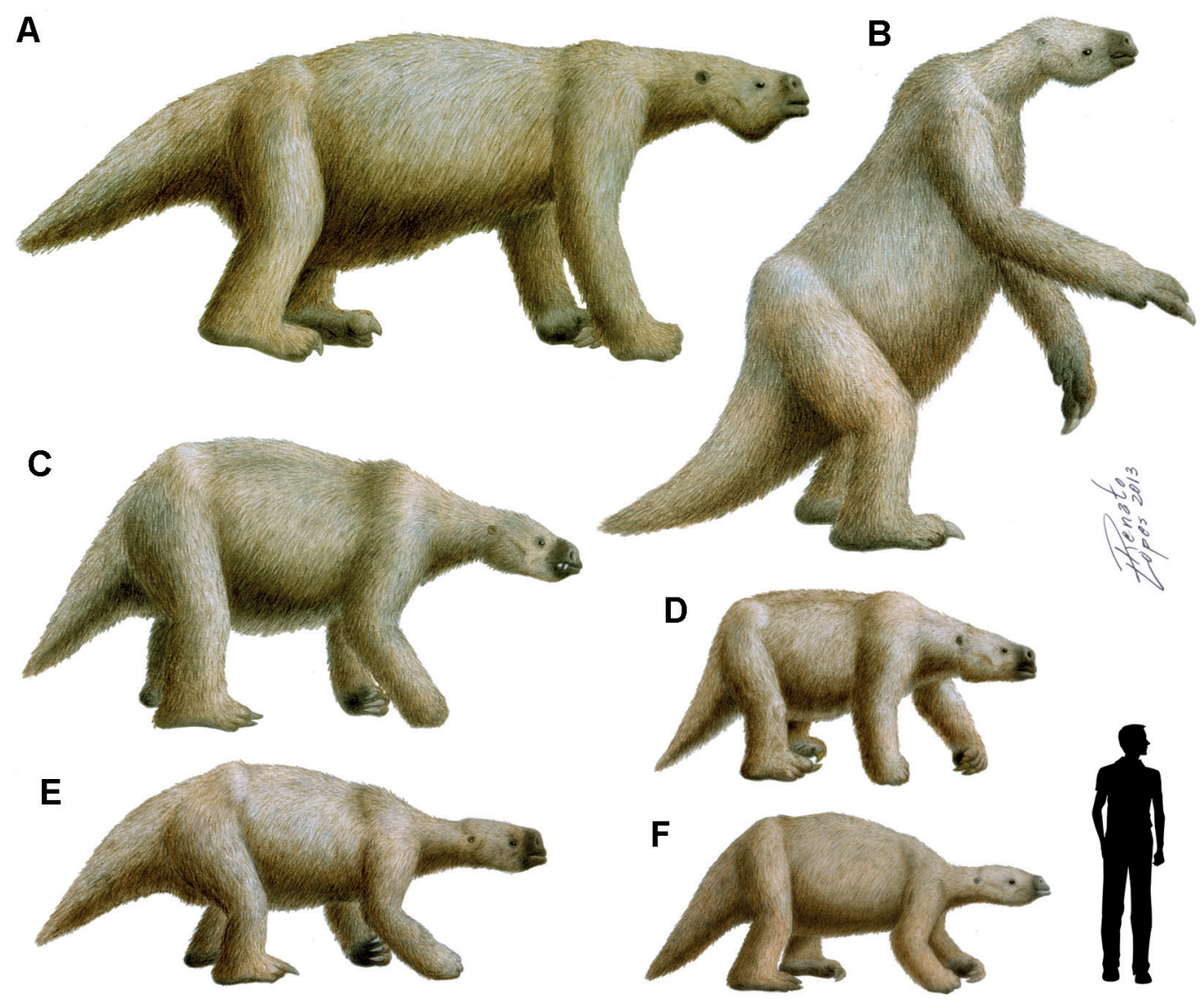

Figure 8. Sloth species found in the fossil assemblages of the CPRS: A, Megatherium americanum; B, Eremotherium laurillardi; C, Lestodon armatus; D, Mylodon darwinii; E, Glossotherium robustum; F, Catonyx cf. C. cuvieri.

cannot be discarded, given the faunal similarity between the paleomastofauna of the two areas and the biostratigraphic correlation of some fossils from the continental shelf, such as Neolicaphrium and Panochthus subintermedius (Scherer et al., 2009; Lopes et al., 2010; Aires \& Lopes, 2012; Ferreira et al., 2015), with units older than the Bonaeran of Argentina. However, more specimens with unambiguous morphological features are necessary in order to assess this hypothesis.

The post mortem features of the tibia MCN-PV1115 suggest a complex taphonomic history. Abraded surfaces are characteristic of fossils continuously reworked in shallower areas by waves and currents (Lopes et al., 2008; Lopes \& Ferigolo, 2015), such as the tibia MCTFM-PV1098 and the astragalus MCTFM-PV1176. The abrasion is concentrated on the posterior side of the proximal and distal epiphyses, thus suggesting that the tibia was lying on its anterior side, mostly covered by sediment but had its posterior side partially exposed above the sediment surface. On the other hand, several portions of the surface are occupied by marine episkeletozoans such as galleries of polychaetes (Spionide), corals (Astrangia rathbuni), oysters (Ostrea $\mathrm{cf}$. O. equestris) and skeletons of bryozoans (Cheilostomata), features observed only in fossils exposed at the sediment-water interface on the continental shelf at depths below the action of waves (Lopes \& Buchmann, 2010; Lopes, 2012). Such combination of features suggests a taphonomic history that possibly included an initial exhumation-abrasion phase at shallower depths during the early marine transgression, followed by a phase of total exhumation and colonization by episkeletozoans as water depth increased in response to sea-level rise.

Fossils of Megatherium were reported from several localities across Rio Grande do Sul (Figure 9), being the only records of this taxon in Brazil. The remains assigned to Megatherium by some authors (Paula Couto, 1953; 1975; Bombin, 1976), however, did not have their taxonomic identity confirmed or could only be regarded as Megatheriidae indet. (Ribeiro \& Scherer, 2009). The only specimens of Megatherium that had been described in detail were a partial dentary and an incomplete femur found in Pessegueiro Creek, county of Caçapava do Sul, in central Rio Grande do Sul (Oliveira et al., 2002). The assignment of the megatheriid remains found on the shoreline and in the Chuí Creek to $M$. americanum by Paula Couto \& Cunha (1965) and Soliani (1973) was probably based on the fact that this taxon is restricted to the meridional areas of South America (Owen, 1861; Paula Couto, 1975; 1979). The record of E. laurillardi in Pessegueiro Creek (Toledo, 1988; Oliveira et al., 2002), and in the CPRS (Pereira et al., 2012) have cast doubt on the taxonomic assignment of incomplete megatheriid remains from Rio Grande do Sul identified as M. americanum.

The fossils found in central Rio Grande do Sul (Oliveira et al., 2002) and presented here are the only fossils of 


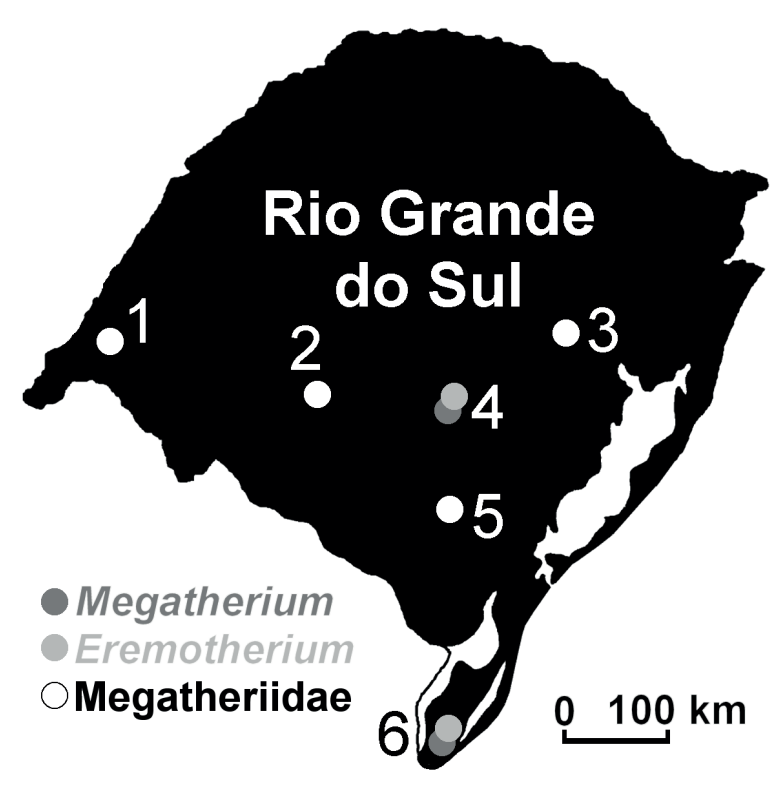

Figure 9. Map of Rio Grande do Sul showing the localities with reported occurrences of fossils of megatheriid sloths: 1, Uruguaiana (Touro Passo Fm.); 2, São Gabriel; 3, Venâncio Aires; 4, Caçapava do Sul; 5, Pinheiro Machado; 6, Santa Vitória do Palmar.

Megatherium from Brazil described so far, and provide unequivocal evidence that both $E$. laurillardi and $M$. americanum inhabited southern Brazil during the Pleistocene. Besides being the southernmost records of E. laurillardi these are also the only known cases of co-occurrence of both species of megatheriids in the same deposits (Pessegueiro Creek and Chuí Creek). This co-occurrence is remarkable from paleogeographical and paleoenvironmental standpoints, considering that the fossil record of $M$. americanum is restricted to subtropical-temperate areas of South America, whereas E. laurillardi is a taxon with widespread occurrences from the southeastern and northeastern Brazil (the Brazilian Intertropical Region) up to North America (Cartelle \& De Iuliis, 1995; Cartelle, 1999; Martinelli et al., 2012; Dantas et al., 2013).

The fossil-bearing deposits of the SVF are located in an area that does not receive input from rivers flowing from the hinterland since at least $\sim 220 \mathrm{ka}$, when a marine transgression formed the Barrier II (see Figure 1). In fact, the stratigraphic position and dating on fossils and sediments indicate that the deposition of the SVF began after the barrier was formed (Lopes et al, 2010; 2014a). This excludes the possibility of transportation of the remains from other areas located to the west of the CPRS, and indicates that the fossil assemblage of the SVF consists of animals that inhabited the southern CPRS. Moreover, the preservation of the skull MCTFM-PV0772 and the dentary of Eremotherium EPMPV0133 (Pereira et al., 2012), does not suggest that these specimens were transported for long distances. This clearly indicates that both taxa inhabited the same area, and then the question is whether both lived at the same time, or at different times.

Co-existence could have been possible if both taxa occupied distinct ecological niches (i.e. browsing vs. grazing), as suggested by differences in tooth and mandibular morphology (DeIuliis, 1996). Another possibility is that the fossils found in Pessegueiro Creek and Chuí Creek represent individuals that were living at the fringe of their respective habitats. The fossils of mammals from temperate (subtropical) and tropical zones found in Upper Pleistocene deposits of southern Brazil, Uruguay and northern Argentina (Cartelle, 1999; Lopes, 2013; Gasparini \& Tonni, 2016; Ubilla et al., 2016) indicate that at some times in the past this area was an ecotone between the intertropical and subtropical zones. The boundary between these belts probably shifted through time, in response to the glacial-interglacial cycles, thus periodically expanding the area of distribution of Eremotherium to the south and of Megatherium to the northeast, and co-existence may have been occurred if there was some overlapping at the limit between these areas.

On the other hand, the cyclic climate changes could have allowed for both species to inhabit the area only at distinct times. In southern South America, including the CPRS, there are also geological indicators of changes in terrestrial environments, with alternating warm-cold and dry-humid phases (Clapperton, 1993; Lopes et al., 2016; Lopes \& Dillenburg, 2017). These changes were probably controlled by latitudinal shifts of climatic belts, accompanied by vegetation and faunal migrations. Thus, considering the time-averaging of some $200 \mathrm{ka}$ of the assemblage of the SVF, the presence of species indicative of different environmental conditions in the same deposits could result from the mixing by postdepositional processes of remains of animals that inhabited the CPRS at distinct times.

\section{CONCLUSIONS}

The presence of the extinct sloth Megatherium americanum in Pleistocene deposits of Chuí Creek (Santa Vitória Formation) and the continental shelf in southern Brazil is here confirmed by fossils with unambiguous diagnostic characters. This species, previously found only in central Rio Grande do Sul, is characteristic of temperate (subtropical) regions of South America, and occurs in the fossil assemblages of Chuí Creek and Pessegueiro Creek together with the subtropical megatheriid Eremotherium laurillardi. This co-occurrence could indicate co-existence, possible if both taxa occupied distinct niches (browsing and grazing), or from the mixing of fossils with distinct ages in time-averaged assemblages, rather than co-existence.

\section{ACKNOWLEDGMENTS}

The authors would like to thank Mr. L. Siciliano and Mr. E. Battilana who found and kindly donated to the museum the tibia MCTFM-PV1098 and the astragalus MCTFMPV1176, respectively; to A.M. Ribeiro and J. Ferigolo (Museu de Ciências Naturais, SEMA, RS) for providing access to and information about the tibia MCN-PV1115, and two anonymous reviewers who made useful comments and corrections which improved the manuscript. 


\section{REFERENCES}

Aires, A.A.S. \& Lopes, R.P. 2012. Representativity of Quaternary mammals from the southern Brazilian continental shelf. Revista Brasileira de Paleontologia, 15:57-66. doi:10.4072/ rbp.2012.1.05

Ameghino, C. \& Kraglievich, L. 1923. Descripción del Megatherium gallardoi descubierto en el Pampeano Inferior de la Ciudad de Buenos Aires. Anales del Museo de Historia Natural de Buenos Aires, 31:145-156.

Behrensmeyer, A.K. 1978. Taphonomic and ecologic information from bone weathering. Paleobiology, 4:150-162. doi:10.1017/ S0094837300005820

Bombin, M. 1976. Modelo paleoecológico e evolutivo para o Neoquaternário da região da Campanha-Oeste do Rio Grande do Sul (Brasil). A formação Touro Passo, seu conteúdo fossilífero e a pedogênese pós-deposicional. Universidade Federal do Rio Grande do Sul, Programa de Pós-Graduação em Geociências, M.Sc. Dissertation, 132 p.

Brandoni, D.; Carlini, A.A.; Pujos, F. \& Scillato-Yané, G.J. 2004. The pes of Pyramiodontherium bergi (Moreno and Mercerat, 1891) (Mammalia, Xenarthra, Phyllophaga): the most complete pes of a Tertiary Megatheriinae. Geodiversitas, 26:643-659.

Brandoni, D.; Soibelzon, E. \& Scarano, A. 2008. On Megatherium gallardoi (Mammalia, Xenarthra, Megatheriidae) and the Megatheriinae from the Ensenadan (lower to middle Pleistocene) of the Pampean region, Argentina. Geodiversitas, 30:793-804.

Buchmann, F.S.C.; Caron, F.; Lopes, R.P.; Ugri, A. \& Lima, L.G. 2009. Panorama geológico da planície costeira do Rio Grande do Sul. In: A.M. Ribeiro; S.G. Bauermann \& C.S. Scherer (eds.) Quaternário do Rio Grande do Sul-Integrando Conhecimentos, Porto Alegre, Sociedade Brasileira de Paleontologia, p. 35-56 (Monografias 1).

Cartelle, C. 1992. Edentata e megamamiferos herbivoros extintos da Toca das Ossos (Ourolândia, Bahia, Brasil). Universidade Federal de Minas Gerais, Ph.D. Thesis, 700 p.

Cartelle, C. 1999. Pleistocene mammals of the Cerrado and Caatinga of Brazil. In: J.F. Eisenberg \& K.H. Redford (eds.) Mammals of the Neotropics, University of Chicago Press, p. 27-46.

Cartelle, C. \& Bohórquez, G.A. 1982. Eremotherium laurillardi Lund, 1842. Determinação específica e dimorfismo sexual. Iheringia (Série Geologia), 7:45-63.

Cartelle, C. \& De Iuliis, G. 1995. Eremotherium laurillardi - the Panamerican Late Pleistocene megatheriid sloth. Journal of Vertebrate Paleontology, 15:830-841. doi:10.1080/02724634 .1995 .10011265

Cartelle, C. \& De Iuliis, G. 2006. Eremotherium laurillardi (Lund) (Xenarthra, Megatheriidae), the Panamerican giant ground sloth: taxonomic aspects of the ontogeny of skull and dentition. Journal of Systematic Palaeontology, 4:199-209. doi:10.1017/ S1477201905001781

Cione, A.L. \& Tonni, E.P. 1999. Biostratigraphy and chronological scale of upper-most Cenozoic in the Pampean Area, Argentina. In: J. Rabassa \& M. Salemme (eds.) Quaternary of South America and Antarctic Peninsula, A.A. Balkema, p. 23-51.

Clapperton, C.M. 1993. Quaternary geology and geomorphology of South America. Elsevier Press, Amsterdam, 779 p.

Clift, W. 1835. Notice on the Megatherium brought from Buenos Aires by Woodbine Parish, Esq. F.R.S. Transactions of the Geological Society, 3:437-450.

Closs, D. 1970. Estratigrafia da Bacia de Pelotas, Rio Grande do Sul. Iheringia (Série Geologia), 3:3-75.
Cunha, F.L.S. 1959. Mamíferos fósseis do Pleistoceno do Rio Grande do Sul. I - Ungulados. Rio de Janeiro, Departamento Nacional de Produção Mineral, Divisão de Geologia e Mineralogia, 47 p. (Boletim 202).

Cuvier, G. 1804. Sur le Megatherium. Annales du Muséum National d'Histoire Naturelle, 5:376-400.

Dantas, M.A.T.; Dutra, R.P.; Cherkinsky, A.; Fortier, D.C.; Kamino, L.H.Y.; Cozzuol, M.A.; Ribeiro, A.S. \& Vieira, F.S. 2013. Paleoecology and radiocarbon dating of the Pleistocene megafauna of the Brazilian Intertropical Region. Quaternary Research, 79:61-65. doi:10.1016/j.yqres.2012.09.006

De Iuliis, G. 1995. Relationships of the Megatheriinae, Nothrotheriinae, and Planopsinae: some skeletal characteristics and their importance for phylogeny. Journal of Vertebrate Paleontology, 14:577-591. doi:10.1080/02724634.1995.100 11579

De Iuliis, G. 1996. A systematic review of the Megatheriinae (Mammalia: Xenarthra: Megatheriidae). University of Toronto, Department of Zoology, Ph.D. Thesis, 781 p.

Delaney, P.J.V. 1965. Fisiografia e Geologia de Superficie da Planície Costeira do Rio Grande do Sul. Porto Alegre, Escola de Geologia - UFRGS, 105 p. (Publicação Especial 6).

Dillenburg, S.R. 1996. O potencial de preservação dos registros sedimentares do sistema deposicional laguna/barreira IV na costa do Rio Grande do Sul. Notas Técnicas, 9:1-11.

Figueiredo, A.G. 1975. Geologia dos depósitos calcários biodetriticos da Plataforma Continental do Rio Grande do Sul. Universidade Federal do Rio Grande do Sul, Programa de PósGraduação em Geociências, M.Sc. Dissertation, 72 p.

Gasparini, G.M. \& Tonni, E.P. 2016. La fauna y los ambientes en el Cuaternario de la Región Pampeana. Contribuciones del $M A C N$, 6:395-402.

Lopes, R.P. 2012. Bioerosion and bioincrustation in body fossils from the Coastal Plain of Rio Grande do Sul state, southern Brazil. In: R.G. Netto; N. Carmona \& F. Tognoli (eds.) Ichnology of Latin America, Porto Alegre, Sociedade Brasileira de Paleontologia, p. 179-194 (Monografias 2).

Lopes, R.P. 2013. Biostratigraphy of the late Pleistocene fossiliferous deposits of the southern Brazilian coastal area. Journal of Mammalian Evolution, 20:69-82. doi:10.1007/s10914-0119173-y

Lopes, R.P. \& Buchmann, F.S.C. 2008. Comparação tafonômica entre duas concentrações fossilíferas (shell beds) da Planície Costeira do Rio Grande do Sul, Brasil. Gaea, 4:65-77.

Lopes, R.P. \& Buchmann, F.S.C. 2010. Pleistocene mammals from the southern Brazilian continental shelf. Journal of South American Earth Sciences, 31:17-27. doi:10.1016/j. jsames.2010.11.003

Lopes, R.P.; Buchmann, F.S.C. \& Caron, F. 2008. Taphonomic analysis on fossils of Pleistocene mammals from deposits submerged along southern Rio Grande do Sul coastal plain, Brazil. Arquivos do Museu Nacional, 66:213-229.

Lopes, R.P.; Buchmann, F.S.C.; Caron, F. \& Itusarry, M.E.G. 2009. Barrancas fossilíferas do arroio Chuí, RS - importante megafauna pleistocênica no extremo sul do Brasil. In: M. Wing; C. Schobbenhaus; M. Berbert-Born; E.T. Queiroz; D.A. Campos; C.R.G. Souza \& A.C.S. Fernandes (eds.) Sítios Geológicos e Paleontológicos do Brasil, Serviço Geológico do Brasil, Comissão Brasileira de Sítios Geológicos e Paleobiológicos, p. 355-362.

Lopes, R.P. \& Dillenburg, S.R. 2017. The sedimentary and paleoclimatic records in the southern coastal plain of Rio 
Grande do Sul, Brazil. In: CONGRESSO DA ASSOCIAÇÃO BRASILEIRA DE ESTUDOS DO QUATERNÁRIO, 16, 2017. Resumos, Bertioga, ABEQUA. Available at http://www.abequa. org.br/anais2017/atual.php; accessed on 04/20/2019.

Lopes, R.P.; Dillenburg, S.R. \& Schultz, C.L. 2016. Cordão Formation: loess deposits in the southern coastal plain of the state of Rio Grande do Sul, Brazil. Anais da Academia Brasileira de Ciências, 88:2143-2166. doi:10.1590/0001-3765201620150738

Lopes, R.P.; Dillenburg, S.R.; Schultz, C.L.; Ferigolo, J.; Ribeiro, A.M.; Pereira, J.C.; Holanda, E.C.; Pitana, V.G. \& Kerber, L. 2014a. The sea-level highstand correlated to marine isotope stage (MIS) 7 in the coastal plain of the state of Rio Grande do Sul, Brazil. Anais da Academia Brasileira de Ciências, 86:1573-1595. doi:10.1590/0001-3765201420130274

Lopes, R.P. \& Ferigolo, J. 2015. Post mortem modifications (pseudopaleopathologies) in middle-late Pleistocene mammal fossils from southern Brazil. Revista Brasileira de Paleontologia, 18:285-306. doi:10.4072/rbp.2015.2.09

Lopes, R.P.; Kinoshita, A.; Baffa, O.; Figueiredo, A.M.G.; Dillenburg, S.R.; Schultz, C.L. \& Pereira, J.C. 2014b. ESR dating of Pleistocene mammals and marine shells from the coastal plain of Rio Grande do Sul state, southern Brazil. Quaternary International, 352:124-134. doi:10.1016/j.quaint.2013.07.020

Lopes, R.P.; Oliveira, L.C.; Figueiredo, A.M.G.; Kinoshita, A.; Baffa, O. \& Buchmann, F.S.C. 2010. ESR dating of Pleistocene mammal teeth and its implications for the biostratigraphy and geological evolution of the coastal plain, Rio Grande do Sul, southern Brazil. Quaternary International, 212:213-222. doi:10.1016/j.quaint.2009.09.018

Lopes, R.P. \& Pereira, J. 2010. Fossils of Scelidotheriinae Ameghino, 1904 (Xenarthra, Pilosa) in the Pleistocene deposits of Rio Grande do Sul, Brazil. Gaea, 6:44-52. doi:10.4013/ gaea.2010.61.05

Martinelli, A.G.; Ferraz, P.F.; Cunha, G.C.; Cunha, I.C.; Carvalho. I.S.; Ribeiro, L.C.B.; Neto, F.M.; Cavellani, C.L.; Teixeira, V.P.A. \& Ferraz, M.L.F. 2012. First record of Eremotherium laurillardi (Lund, 1842) (Mammalia, Xenarthra, Megatheriidae) in the Quaternary of Uberaba, Triângulo Mineiro (Minas Gerais State), Brazil. Journal of South American Earth Sciences, 37:202-207. doi:10.1016/j.jsames.2012.03.006

McDonald, H.G. 2012. Evolution of the pedolateral foot in ground sloths: patterns of change in the astragalus. Journal of Mammalian Evolution, 19:209-215. doi:10.1007/s10914-0179410-0

Oliveira, E.V. 1992. Mamíferos fósseis do Pleistoceno SuperiorHoloceno do Rio Grande do Sul, e seu significado paleoecológico. Universidade Federal do Rio Grande do Sul, Programa de PósGraduação em Geociências, M.Sc. Dissertation, 118 p.

Oliveira, E.V. 1996. Mamíferos Xenarthra (Edentata) do Quaternário do Estado do Rio Grande do Sul, Brasil. Ameghiniana, 33:111-128.

Oliveira, E.V.; Dutra, T.L. \& Zelter, F. 2002. Megaterídeos (Mammalia, Xenarthra) do Quaternário de Caçapava do Sul, Rio Grande do Sul, com considerações sobre a flora associada. Geologia Colombiana, 27:77-86.

Owen, R. 1861. Memoir on the Megatherium, or giant ground sloth of America (Megatherium americanum, Cuvier). London, Williams and Norgate, $84 \mathrm{p}$.

Pascual, R.; Ortega-Hinojosa, E.R.; Gondar, D. \& Tonni, E.P. 1966. Las edades de Cenozóico mamalífero de la Provincia de Buenos Aires. In: A.V. Borrello (ed.) Paleontografia Bonaerense: Vertebrata, Comisión de Investigaciones Cientificas, p. 3-27.
Paula Couto, C. 1953. Paleontologia Brasileira-Mamíferos. Rio de Janeiro, Instituto Nacional do Livro, 516 p.

Paula Couto, C. 1975. Mamíferos fósseis do Quaternário do sudeste brasileiro. Boletim Paranaense de Geociências, 33:89-132.

Paula Couto, C. 1979. Tratado de Paleomastozoologia. Rio de Janeiro, Academia Brasileira de Ciências, 572 p.

Paula Couto, C. \& Cunha, F.L.S. 1965. Nota preliminar sobre o reconhecimento geo-paleontológico do Rio Grande do Sul. Rio de Janeiro, Departamento Nacional da Produção Mineral, Divisão de Geologia e Mineralogia, p. 49-50 (Avulso 40).

Pereira, J.C.; Lopes, R.P. \& Kerber, L. 2012. New remains of late Pleistocene mammals from the Chuí Creek, southern Brazil. Revista Brasileira de Paleontologia, 15:228-239. doi:10.4072/ rbp.2012.2.10

Pitana, V.G.; Esteban, G.I.; Ribeiro, A.M. \& Cartelle, C. 2013. Cranial and dental studies of Glossotherium robustum (Owen, 1842) (Xenarthra: Pilosa: Mylodontidae) from the Pleistocene of southern Brazil. Alcheringa, 37:147-162. doi:10.1080/0311 5518.2012 .717463

Ribeiro, A.M. \& Scherer, C.S. 2009. Mamíferos do Pleistoceno do Rio Grande do Sul, Brasil. In: A.M. Ribeiro; S.G. Bauermann \& C.S. Scherer (eds.) Quaternário do Rio Grande do Sul Integrando Conhecimentos, Porto Alegre, Sociedade Brasileira de Paleontologia, p. 171-191 (Monografias 1).

Rosa, M.L.C.C. 2012. Geomorfologia, estratigrafia de sequências e potencial de preservação dos sistemas Laguna Barreira do Quaternário Costeiro do Rio Grande do Sul. Universidade Federal do Rio Grande do Sul, Ph.D. Thesis, 232 p.

Scherer, C.S.; Pitana, V.G. \& Ribeiro, A.M. 2009. Proterotheriidae and Macraucheniidae (Litopterna, Mammalia) from the Pleistocene of Rio Grande do Sul State, Brazil. Revista Brasileira de Paleontologia, 12:231-246. doi:10.4072/rbp.2009.3.06

Soliani Jr., E. 1973. Geologia da região de Santa Vitória do Palmar, RS, e a posição estratigráfica dos fósseis de mamíferos pleistocenicos. Universidade Federal do Rio Grande do Sul, Programa de Pós-Graduação em Geociências, M.Sc. Dissertation, $88 \mathrm{p}$.

Toledo, N.; De Iuliis, G.; Vizcaíno, S.F. \& Bargo, M.S. 2017. The concept of a pedolateral pes revisited: the giant sloths Megatherium and Eremotherium (Xenarthra, Folivora, Megatheriinae) as a case study. Journal of Mammalian Evolution, 25:525-537. doi:10.1007/s10914-017-9410-0

Toledo, P.M. 1986. Descrição do sincrânio de Eremotherium laurillardi Lund, 1842, taxonomia e paleobiogeografia. Programa de Pós-Graduação em Geociências, Universidade Federal do Rio Grande do Sul, M.Sc. Dissertation, 127 p.

Toledo, P.M. 1998. Locomotory patterns within the Pleistocene Sloths. Belém, Museu Paraense Emilio Goeldi, 192 p.

Ubilla, M.; Corona, A.; Rinderknecht, A.; Perea, D. \& Verde, M. 2016. Marine Isotope Stage 3 (MIS 3) and continental beds from northern Uruguay (Sopas Formation): paleontology, chronology, and climate. In: G.M. Gasparini; J. Rabassa; C. Deschamps \& E.P. Tonni (eds) Marine Isotope Stage 3 in Southern South America, 60 ka B.P.-30 ka B.P., Springer, p. 183-206. doi:10.1007/978-3-319-40000-6

Villwock, J.A. 1984. Geology of the coastal province of Rio Grande do sul, southern Brazil: a synthesis. Pesquisas, 16:5-49.

Villwock, J.A. \& Tomazelli, L.J. 1995. Geologia Costeira do Rio Grande do Sul. Notas Técnicas, 8:1-45.

Received in 27 July, 2018; accepted in 17 January, 2019. 